\title{
Evaluation of Implementing Sukuk for Infrastructure Financing in Indonesia Using the Analytic Network Process
}

\author{
Syifa Fauziah ${ }^{1}$, Nurwahidin ${ }^{2}$, Nurul Huda ${ }^{3}$ \\ \{syifafauzi25@gmail.com ${ }^{1}$; nurwahidin@ui.ac.id ${ }^{2}$; pakhuda@yahoo.com ${ }^{3}$ \} \\ Universitas Indonesia, Indonesia ${ }^{1,2}$ \\ Universitas YARSI, Indonesia ${ }^{3}$
}

\begin{abstract}
The Indonesian government has used sukuk to finance infrastructure since 2013. However, the issuance of sukuk for infrastructure financing is still low compared to the total value of available underlying assets because of many problems and barriers. This study aims to identify priority problems, solutions and strategies in the implementation of sukuk for infrastructure financing from the obligor perspective. The research uses analytic network process method. The results show that the priority of the problem is the low maximum limit for the issuance of sukuk for infrastructure, market risk, the realization of sukuk issuance for infrastructure is still low, the low sukuk market share compared to bonds, monitoring and evaluation of the use of funds is not optimal. The priority of the solution is to push to complete the project on time so that the burden of costs does not increase, increase the maximum limit for issuance of sukuk, increase the issuance of sukuk for infrastructure investment, optimize monitoring and evaluation of the use of funds, open up broad opportunities for foreign investors. The priority strategies are Synergy, innovation, and the use of IT.
\end{abstract}

Keywords: Sukuk, Infrastructure Financing, Islamic Finance, ANP

\section{Introduction}

Infrastructure is an important one for the progress of the country. Without adequate infrastructure, economic mobility hampered. Infrastructure is the index or variable number two that determines the level of state competition in the 2019 Global Competitiveness Report issued by the World Economic Forum [1]. Looking at the level of state competition from the availability of infrastructure, it turns out that Indonesia is still lagging behind neighboring countries. Singapore is the country with the best infrastructure in the world, which ranks first out of 141 countries. Malaysia ranks $35^{\text {th }}$, Brunei ranks $58^{\text {th }}$, and Thailand ranks $71^{\text {th }}$. Indonesia ranks $72^{\text {th }}$, one level below Thailand. It explains that the infrastructure gap in Indonesia is higher compared to neighboring countries. Table 1 explains that the road and connectivity sector received the smallest value of 59.8. Indonesia's road sector infrastructure ranks $109^{\text {th }}$. The quality of roads in Indonesia is also still ranked 60th, whereas roads are the essential infrastructure that will support economic mobility. Indonesia's energy and water resources infrastructure are also still lagging in the order of 95 and 98. 
Table 1. Indonesian Infrastructure Index

\begin{tabular}{|l|cc|}
\hline \multicolumn{1}{|c|}{ Infrastructure } & Score & Rank/141 \\
\hline Transport infrastructure & 56.1 & 55 \\
Road connectivity & 59.8 & 109 \\
Quality of road infrastructure & 52.6 & 60 \\
Railroad density km/1.000 km & 6.5 & 85 \\
Effeciency of train service & 61.1 & 19 \\
Airport connectivity & 100 & 5 \\
Effeciency of air transport service & 65.2 & 56 \\
Liner shipping connectivity & 47.8 & 36 \\
Effeciency of seaport service & 55.8 & 61 \\
Utility infrastructure & 79.4 & 89 \\
Electricity access \% of population & 94.8 & 95 \\
Electricity supply quality \% of output & 94.7 & 54 \\
Exposure to unsafedrinking water \% of population & 65.5 & 98 \\
Reliability of water supply & 62.5 & 74 \\
\hline
\end{tabular}

Source: World Economic Forum, Global Competitiveness Report 2019 [1].

Therefore, to improve infrastructure gap, the Indonesian government continues to encourage infrastructure development in various regions. The infrastructure budget also continues to increase from year to year. The increase in infrastructure budget is not only from the amount but also the portion. The peak was in 2017, the infrastructure budget increase by Rp. 119.2 Trillion compared to 2016 [2]. In 2019 the infrastructure budget touched Rp. 415 Trillion. The increase in the infrastructure budget certainly shows the seriousness of the Indonesian government to improve the country's infrastructure.

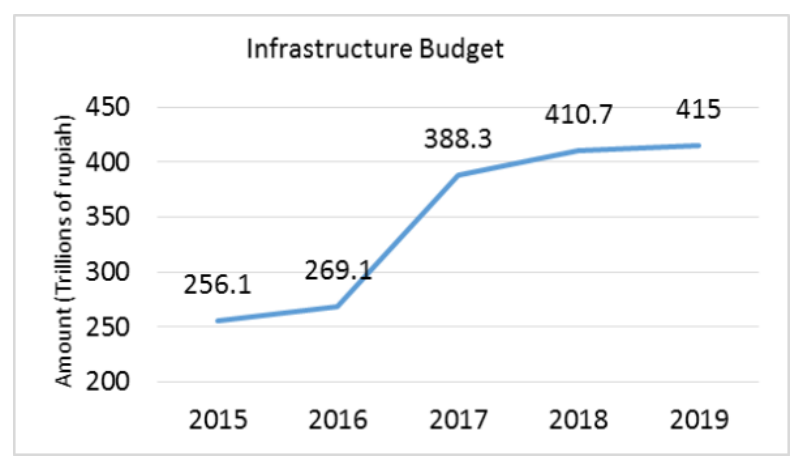

Fig. 1. Indonesian Infrastructure Budget in the APBN [3].

The government issued state sukuk since 2008 to expand the source of the state budget. Since 2013, state sukuk began to earmarked as infrastructure financing instruments [4]. However, until 2019, the issuance of state sukuk for infrastructure has not been maximized. When compared with the available underlying assets, the number of issuances of sukuk is still very far. Underlying assets in question are in the form of infrastructure investment projects and assets owned by the state or State Property (Barang Milik Negara/BMN). 
The Committee for the Acceleration of Priority Infrastructure Providers (Komite Perpecepatan Penyedia Infrastruktur Prioritas/KPPIP) notes that the overall National Strategic Project is estimated to require an investment value of Rp. 4.180 trillion [5]. A total of 81 projects have completed, 27 projects and 2 programs are under construction [5]. The rest of the government still needs an investment of Rp. 2,860 trillion. Supposedly, the value of the investment can be an opportunity for sukuk issuance. Indonesia Ministry of Finance recorded the amount of BMN as of December 2018, reaching Rp. 5,728.49 trillion [4]. The issuance of sukuk until 2019 only reached Rp. 1,221 trillion [3]. The amount is also far from underlying physical assets. It means that of the total available underlying assets, the potential for sukuk issuance can still be a maximum of around Rp. 7,367 trillion.

The sukuk issuance has not been maximally certainly due to obstacles and obstacles that occur. In a report submitted in Bali on October 10, 2018, the Ministry of Finance, as a sukuk issuer, stated the barriers faced in financing infrastructure with state sukuk. Among them; the construction auction process is late, there are problematic contractors, the land is not ready, there are assets lost/destroyed due to disasters and others. So, to continue to encourage the issuance of sukuk to finance infrastructure, evaluation is needed on the current implementation. Especially on the side of the government as a sukuk issuer and policymaker. Then this paper will help look for any problems that occur in the implementation of state sukuk for infrastructure financing. As well as finding solutions and strategies to help evaluate the implementation of state sukuk for infrastructure financing.

\section{Literature Review}

\subsection{Overview}

Sukuk is also called an Islamic bond. In Arabic terminology, sukuk comes from the verb 'tashik', meaning securitization, while the word sukuk comes from the plural word 'Sakk' (Hassan \& Mollah, 2018). The Accounting and Auditing Organization of Islamic Financial Institutions (AAOIFI) defines sukuk as follows:

"Sukuk (plural of Sak) are certificates of equal value representing undivided shares in ownership of tangible assets, usufruct and services or (in ownership of) the assets of particular projects or special investment activity. However, it is true after receipt of the value of sukuk, closing of subscription and employment of funds received for the purpose for which the Sukuk were issued".

Simply stated, sukuk is a letter of ownership of investment assets. The fundamental difference between sukuk and bonds is that the issuance of sukuk requires underlying assets. As an Islamic financial instrument, sukuk must also comply with Shariah compliance before being issued. The suitability of sharia sukuk is the same as the basic principles of sharia economics and finance in general, which sourced from the Qur'an and Hadith. Including; free from usury, gharar and maysir, and obey the rules of halal and haram.

Three rules must be fulfilled in the issuance of sukuk, according to Mutum et al. [6]. First, assets identified as underlying must be sharia-compliant. Second, the information that the obligor gives to investors about the business being invested must be clear. Third, the sukuk structure, contract, and business prospects invested must be clear. 
Sukuk was first published in Indonesia in 2002. Sukuk issued are sukuk owned by PT Indosat. While the Indonesian government only issued sukuk in 2008 after the issuance of Indonesia Law number 19 of 2008 [7]. Sukuk issued by the Indonesian government are referred to as state sukuk or State Sharia Securities (Surat Berharga Syariah Negara/SBSN). ProjectBased Sukuk (PBS) is a series of sukuk issued by the Indonesian government specifically to finance infrastructure projects (earmarked). PBS introduced in 2012 to institutional investors. In 2013 PBS had funded infrastructure development projects [7].

Infrastructure financing with sukuk has two schemes, namely project underlying and project financing. In the underlying project scheme, Hariyanto [8] explained that the infrastructure that had been listed in the APBN would be the basis for issuance. Then the funds from the issuance are used to replace the APBN funds that have been spent on the project whereas project financing allows the project itself to find the funding needed [9]. The project process is also included first in the state budget and then get funding from sukuk (earmarked). Generally, this scheme also emphasizes that the return on capital will come from the results of the project itself [10].

\subsection{Previous Research}

Jatmiko [11] explains the sukuk risk problems faced by obligors. First is the price level risk that occurs when the value of the issuance of the proposed sukuk is different from the value of the asset. The second burden of sukuk costs that must be paid will increase if the project completion is too late from the due date of the agreement. The third credit risk that occurs because there is no preliminary fund provision to overcome the differences in the cycle of disbursement of funds and the time of issuance of sukuk. Finally, market risk is due to the rate of return. Sukuk that have fixed returns will reduce sukuk income when there is an increase in market returns. Nopijantoro [12] also mentioned many infrastructure financings risks with sukuk, namely the delayed completion of the project will result in suboptimal use of funds. The burden of sukuk costs has also increased because it must continue to be paid when due while the infrastructure project has not yet been completed.

Rarasati [9], in her research "Islamic Project Financing in Indonesia Infrastructure Development" also mentioned the problems faced in infrastructure financing with Islamic finance. Among them are the condition of investors who are still profit-oriented and the lack of public knowledge about Islamic finance. Government regulations and policies are also said to be a challenge for the issuance of state sukuk always. Short term investment is more attractive than long term. The problem is that most infrastructure financing projects are long term. In financing, there is a mismatch between the maturity and the time of financing needs.

Other research that discusses the issue of implementing state sukuk was also attended by Beik [13]. According to Beik [13] the economic impact is not apparent because the infrastructure built is not by regional needs. This happens because of the lack of coordination between the central government and local governments regarding the implementation of infrastructure development projects. Project proponents need to be extended to the regions so that they can have a direct impact on the regional economy. Beik [13] also mentioned the lack of investor interest in sukuk investment instruments, lack of public education and socialization regarding sukuk, and the suitability of sharia sukuk which is still being debated.

The problem regarding underlying assets was revealed in a study conducted by Rosyidah et al. [14]. According to him, the sukuk domestic market has issues with limited availability of underlying assets, but not because of the lack of assets owned by the state. That is because there is no updated and reliable data available on state-owned assets, especially regarding productive 
assets that can be used as underlying assets for sukuk issuance. There is no benchmark yield for state assets that can also be a barrier.

Research conducted by Datuk [15] also revealed the problem of the implementation of state sukuk for infrastructure financing. The first is the market of Islamic financial products, which is still low compared to conventional financial products. Secondly, public knowledge about sukuk is still low. The third is the availability of underlying assets. Fourth, about tax regulations. Fifth, the sukuk secondary market has not yet developed, and the sukuk liquidity in the secondary market is still low, investors buy and hold. Sixth, there is no Islamic benchmark, however. Lastly, supporting infrastructure in the context of price discovery to encourage price transparency is not yet perfect.

\section{Method}

This research uses a mixed approach. Data sources used include primary data from filling out questionnaires and in-depth interviews by expert respondents and secondary literature review results. The in-depth interviews and the questionnaire filled out by expert respondents were chosen because of their capacity in understanding the problem in this study.

Table 2. List of Expert Respondents

\begin{tabular}{|c|c|c|}
\hline No & Name & Position \\
\hline 1 & $\begin{array}{l}\text { Dwi Irianti Hadiningdyah, } \\
\text { S.H., M.A. }\end{array}$ & $\begin{array}{l}\text { Director of Islamic Finance in the Directorate General } \\
\text { of Budget Financing and Risk Management, Indonesia } \\
\text { Ministry of Finance }\end{array}$ \\
\hline 2 & M. Faudji & $\begin{array}{l}\text { Head of Section in the SBSN Division, Department of } \\
\text { Islamic Finance, Directorate General of Management } \\
\text { and Financing and Risk, Indonesia Ministry of } \\
\text { Finance }\end{array}$ \\
\hline 3 & Rifki Ismal, Ph.D. & $\begin{array}{l}\text { Head of Division in the Department of Islamic } \\
\text { Economic and Finance, Bank Indonesia (Central Bank } \\
\text { of Indonesia) }\end{array}$ \\
\hline 4 & Ronald Rulindo, Ph.D. & $\begin{array}{l}\text { Director of Product Innovation, Market Deepening } \\
\text { and Financial System Infrastructure Development }\end{array}$ \\
\hline 5 & Farah & $\begin{array}{l}\text { Special Staff of Director of Product Innovation, } \\
\text { Market Deepening and Financial System } \\
\text { Infrastructure Development }\end{array}$ \\
\hline 6 & Yuke Rachmawati, M.A. & $\begin{array}{l}\text { Staff in The Sharia Business and Economic Industries, } \\
\text { National Sharia Board-Indonesian Ulama Council } \\
\text { (DSN-MUI) }\end{array}$ \\
\hline 7 & $\begin{array}{l}\text { Ayomi Dita Rarasati, } \\
\text { Ph.D. }\end{array}$ & $\begin{array}{l}\text { Lecturer and researcher in the management of } \\
\text { infrastructure financing, Universitas Indonesia }\end{array}$ \\
\hline
\end{tabular}
Source: Author, 2019.

The data analysis method uses the Analytic Network Process to analyze priority problems, solutions, and strategies in implementing state sukuk for infrastructure financing in Indonesia. Analytical Network Process (ANP) is the development of the Analytic Hierarchy Process (AHP) method. ANP is a decision-making method developed by Saaty [16]. In the methodological 
framework, ANP is included in the qualitative approach. But ANP can also combine qualitative and quantitative aspects because the use of ANP is flexible for various problems [17]. ANP method is used to solve problems that depend on the criteria contained in the research model. Three basic principles in ANP [17]:

a. Decomposition, constructing complex problems into a hierarchical framework or network of clusters, sub-clusters, and so on.

b. Comparative assessment by pairwise comparisons of all combinations of elements in the cluster or group to get local priorities.

c. Compositions or synthetics that will produce global or overall priorities.

In a comparative assessment that will determine priorities requires a rating scale. The scale of assessment contained in ANP is range 1-9, which explains how important/influential/relevant variable $\mathrm{X}$ is compared to $\mathrm{Y}$ to $\mathrm{Z}$. The stages of the research method carried out refer to the three basic principles of ANP above and are explained through the figure below:

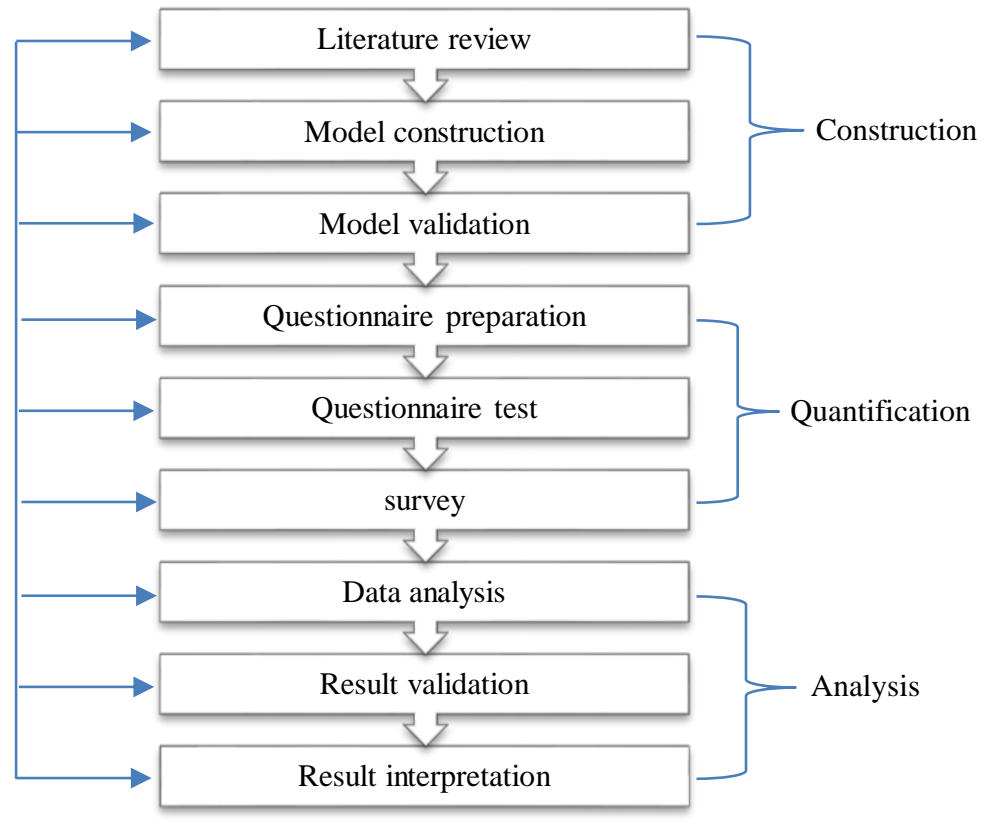

Fig. 2. ANP Research Stages, modified from Ascarya [17].

\section{Finding}

Figure 3 explains that there are 3 (three) areas of evaluation in the implementation of state sukuk for infrastructure financing, namely problems, solutions, and strategies. The conceptual framework model produced by ANP divides problems and solutions into four clusters, namely internal, regulation and policy, risk, and market share. Furthermore, each problem cluster and solution that is reviewed from the obligor perspective has criteria in it that will be compared and produce priorities. 


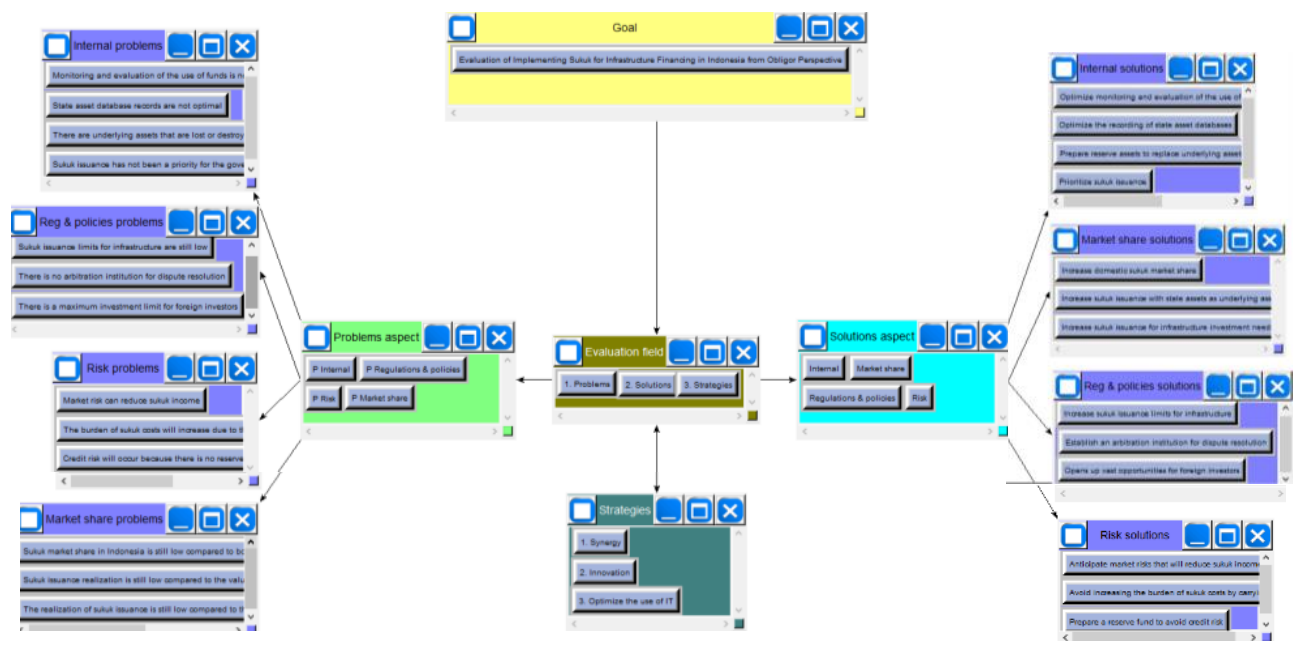

Fig. 3. Conceptual Framework (Author, 2019).

\subsection{Geometric Mean and Inconsistency Ratio}

Like quantitative research in general that uses questionnaires, validity and reliability testing is needed to assess the instruments used. In ANP, validity and reliability can be done by looking at the geometric mean and inconsistency ratio. The smallest geometric mean obtained is 4 and the largest is 9 . Referring to the ANP priority rating scale 4 means important and 9 is very important [18]. That explains that the respondent gives an assessment on an important level to very important on each item submitted questionnaire. The value that often appears is 7 , meaning that many items of the questionnaire are considered very important. In conclusion the criteria proposed in the questionnaire are relevant to the issues raised.

Inconsistency ratios are used to ensure that the proposed criteria or sub-criteria are relevant for comparison [18]. The acceptable inconsistency ratio is a maximum of 0.1 or $10 \%$. The inconsistency value results show the lowest is 0 , and the highest is 0.03703 . All criteria used in the research questionnaire had an inconsistency value of $<0.1 \mathrm{or}<10 \%$. This means that all the proposed criteria are acceptable and relevant for comparison.

\subsection{Priorities of Problems, Solutions, and Strategies}

The results of the decomposition divided through evaluation aspects into four clusters, namely; internal, regulation and policies, risk, and market share. The questionnaire gave the result that the main problem in the implementation of state sukuk for infrastructure financing was the issuance sukuk limits for infrastructure are still low with a value of $52.95 \%$ (Figure 4). The second priority issue is late construction projects that will increase the burden of sukuk costs with a value of $51,94 \%$. The third priority problem with a value of $43,40 \%$ is the realization of sukuk issuance is still low compared to the value of infrastructure investment needs. The fourth priority issue is the market share sukuk in Indonesia is still low compared to bonds with a value of $35,95 \%$. The fifth priority is monitoring, and evaluation of the use of funds is not optimal with a value of $35,37 \%$. 


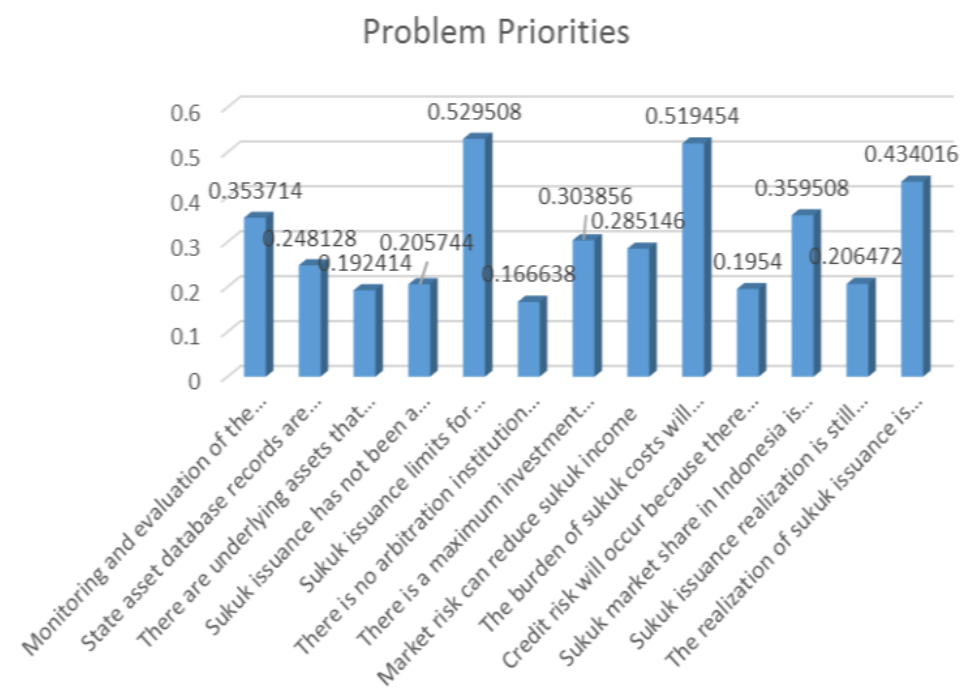

Fig. 4. Problem Priorities (Author, 2019).

The low limit of sukuk issuance for infrastructure is a major problem. This problem is included in the cluster of regulatory and policy issues. According to Mr. Rulindo, one of the expert respondents from KNKS, the maximum limit for the issuance of sukuk for infrastructure depends on the value of the project that is ready. Because sukuk cannot be issued if the project used as an underlying asset is not ready. Ms. Farah, a practitioner from KNKS also conveyed the following explanation;

"In 2018, project-based sukuk will reach Rp. 28 trillion, then the following year the amount will decrease. We had a discussion and asked why the issuance of sukuk dropped and the answer was because the number of projects ready also declined. So, the readiness of the project affects the amount of issuance of sukuk, not limited".

Based on the theory, one of which must be considered in the issuance of sukuk is a definite underlying asset [6]. If the project itself becomes underlying, the project should be ready. This also relates to the suitability of Islamic sukuk. So, the issue of issuance of sukuk limits for infrastructure, in essence, depends on the problem of project readiness.

The second priority issue is included in the risk problem cluster, namely the problem of increased cost burden due to late project completion. This relates to the government's ability to repay sukuk funds to investors when they are due. Mr. Faudji, a practitioner of the Ministry of Finance's Sharia Financing Directorate, stated that one of the crucial risks for the government is a fiscal risk. He said that sukuk financing does not stand alone. In the APBN there are several other sources of funds, each of which has a risk analysis portion. So, it is another source of funds that will be used for example, for refinancing or for other things. But if this problem continues to occur, of course, infrastructure financing with sukuk will be challenging to develop.

Mr. Faudji also explained that if there were a failure to pay, the assets which were used as the underlying would be held up. This risk only happens to the government and has no impact on investors. Ms. Hadiningdyah, head of the Sharia Finance Directorate of the Ministry of 
Finance of the Republic of Indonesia, also said, "if the government is truly unable to pay, investor rights will be made into debt, but the underlying remains impractical because buying and selling are rights, not physical benefits". From this explanation, it can be interpreted that the risk for the government is to be no longer able to use the assets as the underlying because the assets are held as long as the return of sukuk funds is completed.

The third and fourth priority issues are included in the problem cluster regarding market share. The realization of sukuk issuance, which is still low compared to infrastructure investment needs, is the third priority issue. This problem indeed cannot be separated from the problem of project readiness as a statement said by Mr. Rulindo that the government could issue sukuk with great value to finance infrastructure. But the project must be ready. It is what distinguishes sukuk investment from bonds. Any bond can be issued, but sukuk issuance must be based on underlying value. If the project to be used as an underlying is not ready, the project value cannot be estimated yet. Projects that are not ready cannot be used as underlying because they cannot be transferred to investors.

Sukuk's market share in Indonesia, which is still low compared to bonds, is the fourth priority issue. Regarding this, Ms. Hadiningdyah argues that the market share of sukuk and obligations cannot be compared because there are many different characteristics between them. The historical issuance of sukuk in Indonesia must also be taken into account because the bonds had already been issued in 2002:

“...history of the country's bonds issued earlier in 2002, but previously regularly in the government market has issued 600 trillion, so the start was in the amount of 600 trillion. Bonds have started 6 years earlier than sukuk. So, there are more in the market whereas sukuk were issued in 2008 and in August (mid-year). First published 2008 only once and starting from zero".

The problem is a challenge for the government if you want to increase sukuk market share in Indonesia. Although internationally, sukuk issuance in Indonesia has begun to dominate [4]. But rising domestic market share is also very important to build independence in financing national development. As Ms. Rachmawati UIN academic Syarif Hidayatullah and Practitioners at DSN-MUI, who said that if sukuk has a good market share in Indonesia, will certainly have a good impact on the Indonesian economy. That is because money does not flow out, but only revolves in the domestic market.

The last priority problem is the problem of monitoring and evaluating the use of funds that have not been optimal. This problem is included in the cluster of internal problems that occur on the obligor side. Faudzi explained that sukuk for infrastructure financing has been earmarked for specific infrastructure projects, so the project must be completely completed. So, to mitigate sukuk investment money will not be a stalled project, there are ways taken by the government such as the presentation of Faudzi:

"First, the government will select ready projects. Second, the government provides an opportunity to complete the project even though the tempo has been lost. Third, the government will monitor the planning, also though monitoring evaluation is not on site. Sukuk financing is different from funding direct with pure rupiah. Funding infrastructure with pure rupiah under the Ministry of Finance also, there is no project monitoring plan, only recording withdrawals. Whether the project is completed or not is no longer the responsibility of the finance minister". 
Responsibility for the use of funds is ultimately the responsibility of the obligor to investors because it is the obligor who needs funds for infrastructure development. But for the state sukuk issued by the Indonesian government, the finance ministry is only an obligor and SPV and not a user of funds. In this case, the user of the fund is not the obligor directly, but the ministries and institutions that have infrastructure development projects. Therefore, obligors must encourage departments and institutions that use sukuk funds so that investment funds are truly utilized optimally.

Then, the results of solution priorities are summarized in figure 5. The priority of the solution that had to be done was that the government first had to push for the completion of sukuk-funded projects on time so as not to increase the burden of sukuk costs. The solution gets a value of $54,18 \%$. Second, increasing the maximum limit of sukuk issuance for infrastructure financing with a value of $48,13 \%$. Third, increase sukuk issuance to meet infrastructure investment needs with a value of $41,98 \%$. Fourth, optimize monitoring and evaluation of the use of funds with a value of $39,52 \%$. The last priority of solution with a value of $35,01 \%$ is opens up vast opportunities for foreign investors.

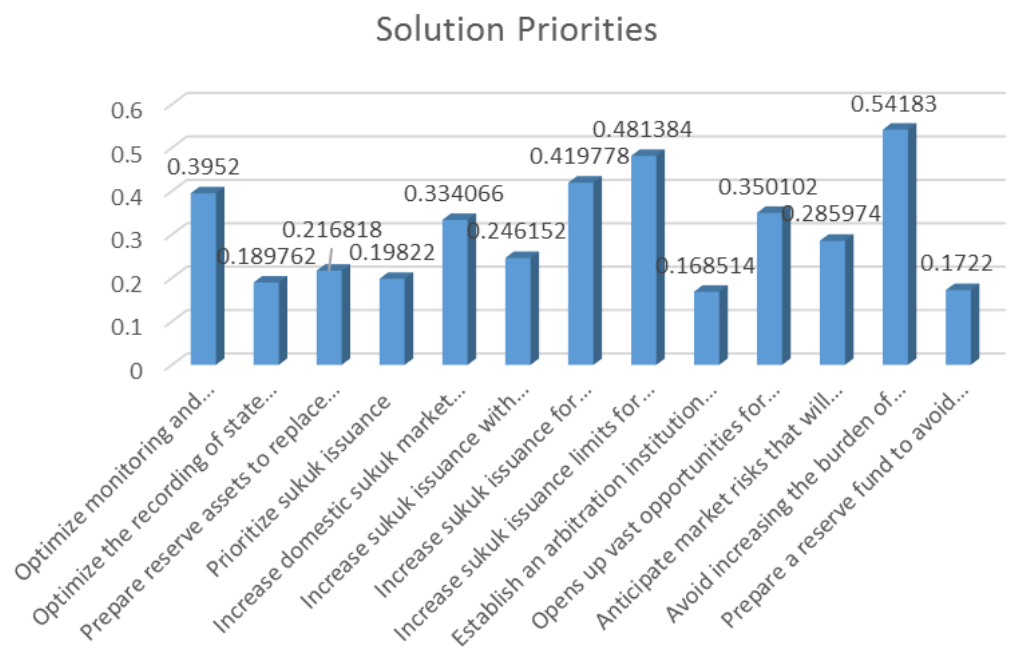

Fig. 5. Solution Priorities (Author, 2019).

Sukuk have an agreed maturity between the obligor and the investor. Late project completion is a significant obstacle to the development of sukuk financing for infrastructure. Late project completion can result in increased cost burdens. It is a risk for the government as an obligor. Ministries and Institutions that manage sukuk funds should be able to complete infrastructure projects on time so that the burden of sukuk costs does not increase. Although Hadiningdyah explained that there had been many ways taken to monitor and evaluate ministries and institutions in completing projects.

"...There is an evaluation forum. The evaluation forum is to bring together ministries and institutions whose performance is still low. We also invite those with excellent performance to give testimonials and sharing sessions. Then we also hold a high- 
level meeting. At the High-level meeting, we invited the heads of ministries and agencies to inform about sukuk financing and how the financing process is".

So far, the government has indeed carried out monitoring and evaluation. There are still projects that are overdue and not even completed until the end of the contract period. Therefore, encouraging project completion on time to avoid increasing costs is always a priority solution in evaluating the implementation of state sukuk for infrastructure financing. The solution is included in the risk cluster.

The second solution priority that can be done is to increase the limit on the issuance of sukuk and to be included in the regulatory and policy solution cluster. It has been explained previously that the limit for issuance of sukuk depends on the value of the project when using a project financing scheme [9]. Project financing means the project itself will be underlying. So, to increase the maximum limit for the issuance of sukuk, the government needs to encourage ministries and institutions to prepare projects as well as possible. Regarding project readiness, in addition to sharia compliance, this has also been regulated in Government Regulation Number 56 of 2011 concerning project requirements that can be financed by state sukuk. One of them is that the project has fulfilled the readiness and feasibility criteria to be implemented.

The third priority solution that can be implemented is increasing sukuk issuance to meet infrastructure investment needs. The solution is included in the market share cluster. One of the main objectives of the government in issuing sukuk is to finance infrastructure [4]. In line with this goal, the government should continue to increase the issuance of sukuk to meet the infrastructure investment needs. Besides, the government must also prioritize the issuance of sukuk to finance infrastructure development compared to other instruments. Because according to Ismal, currently, the government has not prioritized sukuk issuance.

"The problem is because the tendency to prioritize state sukuk as an alternative to infrastructure financing is still not high. The government always prioritizes conventional instruments first, sukuk only to complete. Whereas sukuk from the financial side is better because there are underlying assets, then sukuk enthusiasts are also relatively high".

Another critical solution for the government is to increase the monitoring and evaluation of the use of funds. It is the fourth priority solution included in the internal cluster. This solution is important so that it can be known that the funds that have been invested by investors can be optimally absorbed and utilized. According to Rachmawati, something like this is essential because the problem of using funds is still prone to corruption. If that happens, of course it will also affect the quality of the resulting construction. Monitoring and evaluating the use of sukuk funds is also crucial because it involves the benefit of investment funds. Because basically every Islamic financing must contain elements of advantages and maslahah for the people [19].

The fifth solution priority is to open broad opportunities for foreign investors to invest through sukuk instruments. In recent years, Indonesia's Islamic finance industry has experienced a significant increase. One of the reasons for this is the issuance of state sukuk. In fact, Indonesia is one of the largest global sukuk cultivators in the world [3]. But according to Rachmawati, although Indonesia's global sukuk is the largest, the results of sukuk investment do not yet have a significant economic impact. So, the solution to open up broad opportunities for foreign investors by increasing global sukuk issuance is still a priority solution that can be considered for the development of the sukuk financial industry. 
After problems and solutions, this research also outlines priority strategies that can accelerate the steps in evaluating the implementation of state sukuk for infrastructure financing. The first strategic priority is a synergy to obtain results in the amount of $39.07 \%$. The second priority is an innovation that is equal to $35.72 \%$. Finally, the optimization of IT usage is $25.21 \%$.

\section{Strategy Priorities}

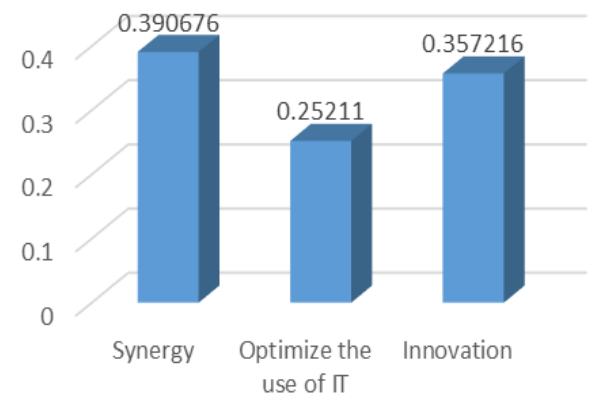

Fig. 6. Strategy Priorities (Author, 2019).

Synergy is a top priority as a way to accelerate steps in evaluating the implementation of state sukuk for infrastructure financing. Based on the results of the priority problems and solutions above, the synergy between institutions is indeed a critical strategy carried out by the government. Given the priority problems that arise are regarding delays in project implementation, which can lead to suboptimal use of funds or even add to the burden of costs. So, to solve this problem, the Ministry of Finance of the Republic of Indonesia as an obligor can increase synergy with the ministries and the project initiating agency.

Innovation is the second strategic priority. Innovations can be made to increase market share, both domestically and abroad. One example of innovation that has been done by the government is by making green sukuk products. The presence of a new variant of sukuk that raises environmental issues is certainly expected to increase interest, especially investors who care about the environment. In the future, to continue expanding sukuk market share, innovation must continue to be made so that sukuk products continue to be increasingly in demand.

The final solution priority is to optimize the use of IT. The use of IT can be optimized, for example for the process of monitoring and evaluating the use of funds through e-budgeting. IT can also be used to monitor submissions for ministries and project proponents (initiators), and for other things that can optimize the implementation of sukuk for infrastructure financing. But what should be considered in optimizing the use of IT is human resources and supporting technology infrastructure.

\section{Conclusion and Implication}

There are four problem clusters and solutions faced by obligors in implementing state sukuk for infrastructure financing in Indonesia. The four clusters are internal, market share, regulations and policies, and risks. Among the problems divided into the four clusters, ANP gave the result that the problem that became the first priority was the limit of sukuk issuance 
which was still low. Second, the burden of increased costs due to late completion of the project. Third, the realization of sukuk issuance for infrastructure is still low compared to the value of infrastructure investment needs. Fourth, market share sukuk in Indonesia is still low compared to bonds. The fifth is monitoring and evaluation of the use of funds is not optimal.

The solution priority is the first to encourage project completion on time so as not to increase the burden of sukuk costs. Second, to increase the maximum limit for the issuance of sukuk for infrastructure financing. Third, increase sukuk issuance to meet infrastructure investment needs. Fourth, Optimize monitoring and evaluation of the use of funds. Fifth, to open up opportunities for foreign investors. The priority strategies that can be implemented are synergy, innovation, and optimizing the use of IT.

This research contributes to the field of Islamic finance, especially regarding sukuk instruments for infrastructure financing. The results can contribute to assisting the government in evaluating the implementation of state sukuk for the infrastructure financing. Due to the development of the Islamic finance industry in Indonesia, especially the state sukuk instrument. Research is needed in this area because state sukuk is an instrument that dominates the Islamic financial market in Indonesia. State sukuk has been trusted to be a safe investment instrument because it has an underlying and guaranteed by the state. Then you don't have to worry about losing money if you invest in state sukuk.

\section{Acknowledgments}

We thank Universitas Indonesia for funding this research.

\section{References}

[1] World Economic Forum, "Global Competitiveness Report 2019," World Economic Forum, 2019.

[2] Kementerian Keuangan, "Investasi syariah melalui Surat Berharga Syariah Negara (sukuk negara)," Kementerian Keuangan, 2017.

[3] Kementerian Keuangan, "Pembiayaan proyek infrastruktur melalui penerbitan SBSN/ sukuk negara," Kementerian Keuangan, 2018. [Online]. Available: https://www.djppr.kemenkeu.go.id/upload/files/Sosialisasi-SBN-Creative--and-innovativefinancin.

[4] Kementerian Keuangan, "Peran sukuk negara dalam pembisssssayaan pembangunan berkelanjutan,” Kementerian Keuangan, 2018. .

[5] Komite Perpecepatan Penyedia Infrastruktur Prioritas, "Proyek Strategis Nasional," Komite Perpecepatan Penyedia Infrastruktur Prioritas, 2019. [Online]. Available: https://kppip.go.id/proyek-strategis-nasional/ .

[6] D. Mutum, M. M. Butt, and M. Rashid, Advances in Islamic Finance, Marketing, and Management: An Asian Perspective. Emerald Group Publishing, 2016.

[7] M. E. Nasution and N. Huda, Investasi pada pasar modal syariah. Kencana, 2019.

[8] E. Hariyanto and D. P. Pembiayaan, "Memahami Project Based Sukuk (PBS). 5," Sumber, vol. 346, no. 6, pp. 2-70, 2017.

[9] A. D. Rarasati, "Islamic project financing in Indonesian infrastructure development." Queensland University of Technology, 2014.

[10] A. D. Rarasati, E. Too, B. Trigunarsyah, and F. Cheung, "Islamic project financing implementation for sustainable infrastructure development in Indonesia," in Proceedings of the 2nd International Conference on Sustainable Technology Development (ICSTD 2012), 2012, pp. C24-C32.

[11] Jatmiko, "Kendala dan kelayakan Surat Berharga Syariah Negara (SBSN)/ sukuk negara sebagai 
alternatif pembiayaan proyek infrastruktur," Universitas Indonesia, 2012

[12] W. Nopijantoro, "Surat Berharga Syariah Negara Project Based Sukuk (SBSN PBS): sebuah Instrumen Alternatif Partisipasi Publik dalam Pembiayaan Infrastruktur,” Substansi, vol. 1, no. 2, pp. 390-406, 2018.

[13] I. S. Beik, "Memperkuat Peran Sukuk Negara Dalam Pembangunan Ekonomi Indonesia," $A L-$ INFAQ, vol. 2, no. 2, 2011.

[14] E. R. Aprilia, S. Sunarti, and E. Pangestuti, "Pengaruh daya tarik wisata dan fasilitas layanan terhadap kepuasan wisatawan di Pantai Balekambang Kabupaten Malang," J. Adm. Bisnis, vol. 51, no. 2, pp. 16-21, 2017.

[15] B. Datuk, "Sukuk, dimensi baru pembiayaan pemerintah untuk pertumbuhan ekonomi," J. Ris. Akunt. dan Bisnis, vol. 14, no. 1, 2014.

[16] T. L. Saaty, "How to make a decision: the analytic hierarchy process," Eur. J. Oper. Res., vol. 48, no. 1, pp. 9-26, 1990.

[17] Ascarya, Konsep dasar Analytic Network Process (ANP) pendekatan baru dalam penelitian kualitatif. Jakarta: Pusat Pendidikan dan Studi Kebanksentralan: Bank Indonesia, 2009.

[18] R. W. Saaty, "Decision making in complex environments," Super Decis., 2003.

[19] A. Hassan and S. Mollah, "Islamic Finance: A Global Alternative," in Islamic Finance, Springer, 2018, pp. 19-30. 